\title{
Comparative Study of Estimation of Asprine from Commercial Sample by UV - Visible Spectrophotometer and Hplc Method
}

\author{
S. R. Ambadekar", G. R. Barabde \\ Department Of Chemistry, Institute Of Science, Fort Mumbai-32 India
}

\begin{abstract}
Simple and accurate spectrophotometric and HPLC method was developed for determination of Aspirin in tablets dosage form. The spectrophotometric method was by dissolving tablets in 1:1 methanol to make solution of 10 ppm giving absorbance at $220 \mathrm{~nm}$. The experimental conditions were optimized and Beers law was obeyed over the applicable concentration range. The application of HPLC procedure depends on using a conventional reverse phase (C18) column along with mobile phase consisting of 1:1 Methanol. Both techniques were applied successfully for analysis of Aspirin in five different commercially available tablets. From the results obtained for both procedures percentage purity was found out.
\end{abstract}

Key Words: Aspirin, spectrophotometric, HPLC method, Methanol

\section{Introduction}

Aspirin is commonly encountered organic poison after Barbiturates. The lethal dose for an adult is very large but much more dangerous to children, who are fatally poisoned by it with distressing frequency. Its identification in fatal cases is easy because its low toxicity means that plenty will be recovered. Aspirine overdose causes hypertension which cause patients $\mathrm{PCo} 2$ drop from normal limits. The body will try to compensate for this by excreting bicarbonates which result in increase inpH blood levels. If this is not corrected it will lead to metabolic alkalosis.(1) Literature survey showed number of method of analysis for the detection of presence of salicylic acid and Acetyl salicylic acid in delayed release aspirin tablet by second derivative UV spectrophotometer.(2).Similarly Asprine and paracetamol by UV spectrophotometer(3), There was successful investigation of of salicylic acid by electrochemical oxidation on a glassy carbon electrode using cyclic voltammetry and differential pulse voltammetric (DPV) method (4). Aspirin, Paracetamol, Caffeine, and Chlorphenamine Using Multivariate Regression Methods by spectrophotometer, Acetylsalicylic acid, paracetamol, caffeine and phenobarbital by HPLC Method(5,6). But there was a need to develop rapid method for detection of presence of Asprine quantitatively which require fewer chemicals and less man powar.The method was developed using differently commercially available drug sample which are usually prescribed or bought over the counter.<smiles>CC(=O)Oc1ccccc1C(=O)O</smiles>

\section{Material And Methods}

: 1) HPLC - An Agilent 1100 liquid chromatograph equipped with a G 1322A Degassar, G1311AQuatrz form and DAD1315D detector was used for chromatographic measurements. The chromatograms were recorded and the peaks were quantities using automatic integrator.

2) UV-Visible spectrophotometer

3) Preparation of standard solutions

For spectrophotometric determination -Standard solution of Aspirin was prepared of $100 \mathrm{ppm}$ concentration. Using that standard solution a series of dilutions ranging from $4 \mathrm{ppm}$ to $20 \mathrm{ppm}$ were prepared.

For HPLC determination -Standard solution of Aspirin was prepared of $1000 \mathrm{ppm}$ concentration. Using that standard solution a series of dilutions ranging from $40 \mathrm{ppm}$ to $200 \mathrm{ppm}$ were prepared.

4) 1:1 methanol

5) Tablets Taken For Analysis 


\section{Table No.1}

\begin{tabular}{|c|c|c|c|}
\hline Name of Samples & Name of manufacturer & Batch number & Amount of Asprine per tablet \\
\hline Disprine & Reckitt Benckiser (India) Ltd & M01085 & $350 \mathrm{mg}$ \\
\hline Ecosprine & Kalindi Medicure Pvt Ltd & DLS-10012 & $75 \mathrm{mg}$ \\
\hline Loprine & Benkiser (India) & A-025 & $75 \mathrm{mg}$ \\
\hline Delsprine & USV LTD & 13004136 & $75 \mathrm{mg}$ \\
\hline ADR & Zydus Health Care & ZHK 3560 & $50 \mathrm{mg}$ \\
\hline
\end{tabular}

6) Preparation Of Sample Solution For Analysis by Uv - Visible spectrophotometer

For Spectrophotometric determination the contents of ten tablet strip was accurately weighed and powdered in a mortar. Exact $10 \mathrm{mg}$ of sample was taken in $25 \mathrm{ml}$ volumetric flask and diluted with 1:1Methanol. The solution was mechanically shaken and then filtered through membrane filter. As per Table no. 2 according to Aspirin present in given sample the corresponding volume was taken and volume made up to $25 \mathrm{ml}$ by 1:1 Methanol to get solution of $10 \mathrm{ppm}$ of each sample.

Table No.2

\begin{tabular}{|l|l|l|l|l|l|l|l|}
\hline Sample & $\begin{array}{l}\text { Wt. of } \\
\text { sample } \\
\text { tablet } \\
(\mathrm{Mg})\end{array}$ & $\begin{array}{l}\text { Asprine } \\
\text { present in } \\
\text { tablet } \\
(\mathrm{mg})\end{array}$ & $\begin{array}{l}\text { First } \\
\text { dilution } \\
(\mathrm{ml})\end{array}$ & $\begin{array}{l}\text { Concentration of } \\
\text { solution } \\
(\mathrm{ppm})\end{array}$ & $\begin{array}{l}\text { Volume } \\
\text { required for } \\
\text { final dilution } \\
(\mathrm{ml})\end{array}$ & $\begin{array}{l}\text { Final } \\
\text { dilution }\end{array}$ & Final concentration \\
$(\mathrm{ppm})$
\end{tabular}

7) Preparation Of Sample Solution For Analysis by HPLC

For HPLC determination the contents of ten tablet strip was accyrately weighed and powdered in a morter. Exact $100 \mathrm{mg}$ of sample was aken in $25 \mathrm{ml}$ volumetric flask and diluted with 1:1 Methanol. The solution was mechanically shaken and then filtered through membrane filter. As per Table no. 2 according to Asprine present in given sample the corresponding volume was taken and volume made upto $25 \mathrm{ml}$ by $1: 1$ Methanol to get solution of $80 \mathrm{ppm}$ of each sample.

Table No.3

\begin{tabular}{|l|l|l|l|l|l|l|l|}
\hline Sample & $\begin{array}{l}\text { Wt. of } \\
\text { sample } \\
\text { tablet } \\
(\mathrm{Mg})\end{array}$ & $\begin{array}{l}\text { Asprine } \\
\text { present in } \\
\text { tablet } \\
(\mathrm{mg})\end{array}$ & $\begin{array}{l}\text { First } \\
\text { dilution } \\
(\mathrm{ml})\end{array}$ & $\begin{array}{l}\text { Concentration of } \\
\text { solution } \\
(\mathrm{ppm})\end{array}$ & $\begin{array}{l}\text { Volume } \\
\text { required for } \\
\text { final dilution } \\
(\mathrm{ml})\end{array}$ & $\begin{array}{l}\text { Final } \\
\text { dilution }\end{array}$ & Final concentration \\
$(\mathrm{ppm})$ & & & \\
\hline Disprine & 100 & 64.70 & 25 & 2588 & 0.77 & 25 & 80 \\
\hline Ecosprine & 100 & 79.78 & 25 & 3191 & 0.63 & 25 & 80 \\
\hline Loprine & 100 & 35.62 & 25 & 1424 & 1.40 & 25 & 80 \\
\hline Delsprine & 100 & 68.18 & 25 & 2727 & 0.73 & 25 & 80 \\
\hline ADR & 100 & 37.25 & 25 & 1490 & 1.34 & 25 & 80 \\
\hline
\end{tabular}

\section{Result And Discussion:}

Analysis By Uv And Visible Spectrophotometer.

For UV-visible spectrophotometer the $\lambda$ max value for standard solution was found to be $220 \mathrm{~nm}$. The calibration graph when plotted using different concentration of Aspirin sample was found to be straight line passing through origin obeying Beer's law. Using this calibration graph values for samples were found out which are depicted in table no. 4. They were all found in range using their values percentage recovery was calculated which was found to be in range as shown in table no.4, 


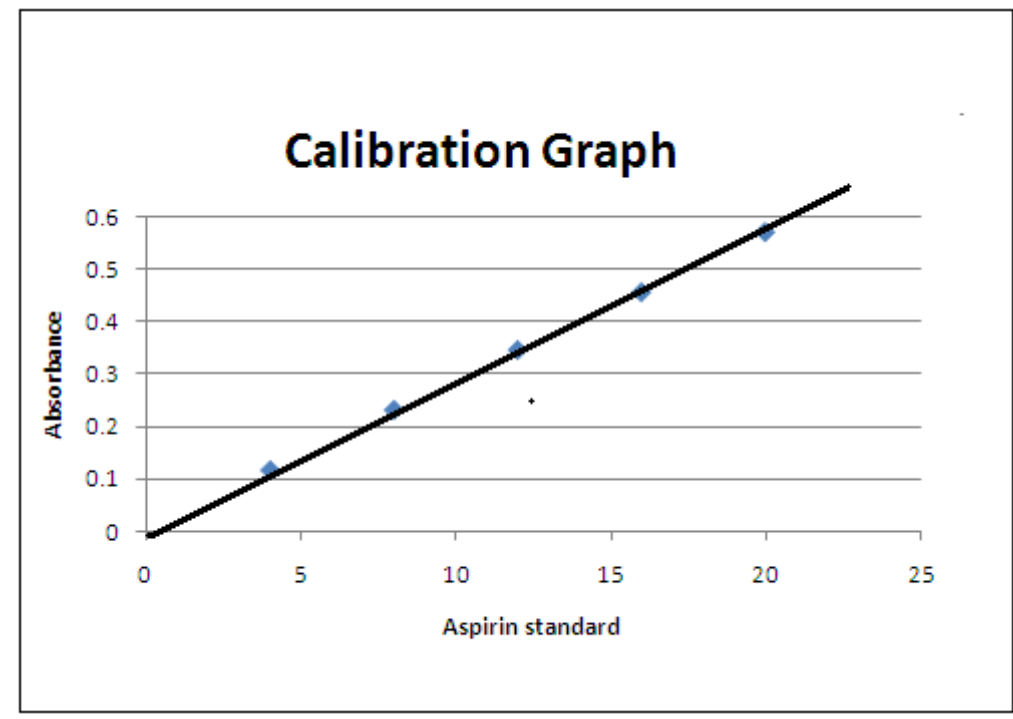

Table No.4

\begin{tabular}{|c|c|c|c|c|c|}
\hline Sample & Concentration & $\begin{array}{c}\text { Absorbance } \\
\text { at 220nm } \\
\text { (OD) }\end{array}$ & \% Assay & $\begin{array}{c}\text { Label claim } \\
\text { on sample }\end{array}$ & Recovery \\
\hline Disprine & 10 & 0.2779 & 341.9 & 350 & 97.70 \\
\hline Ecosprine & 10 & 0.2802 & 74.05 & 75 & 98.73 \\
\hline Loprine & 10 & 0.2760 & 72.63 & 75 & 96.85 \\
\hline Delsprine & 10 & 0.2841 & 74.81 & 75 & 99.75 \\
\hline ADR & 10 & 0.2799 & 49.11 & 50 & 98.22 \\
\hline
\end{tabular}

Analysis By Hplc Method

\begin{tabular}{|c|c|c|c|c|c|}
\hline Sample & Concentration & $\begin{array}{c}\text { Area at 280nm } \\
(\mathrm{mAu})\end{array}$ & $\%$ Assay & $\begin{array}{c}\text { Label claim } \\
\text { on sample }\end{array}$ & $\%$ Recovery \\
\hline Disprine & 80 & 821532 & 342.33 & 350 & 97.80 \\
\hline Ecosprine & 80 & 830379 & 74.15 & 75 & 98.86 \\
\hline Loprine & 80 & 810298 & 72.30 & 75 & 96.40 \\
\hline Delsprine & 80 & 832454 & 74.30 & 75 & 99.07 \\
\hline ADR & 80 & 823974 & 49.01 & 50 & 98.02 \\
\hline
\end{tabular}

$\%$ Assay $=\underline{\text { OD of sample }} \times \underline{\text { std weight }} \times \underline{\text { vol of std solu required }} \times \underline{\text { dilu. of sampl }} \times$ Avg wt ofsample OD of std first dilution final dilu. Of std aspirine pres in samp

$\%$ Recovery $=$ $\%$ Assay $\mathrm{X} 100$

Lable claim on sample

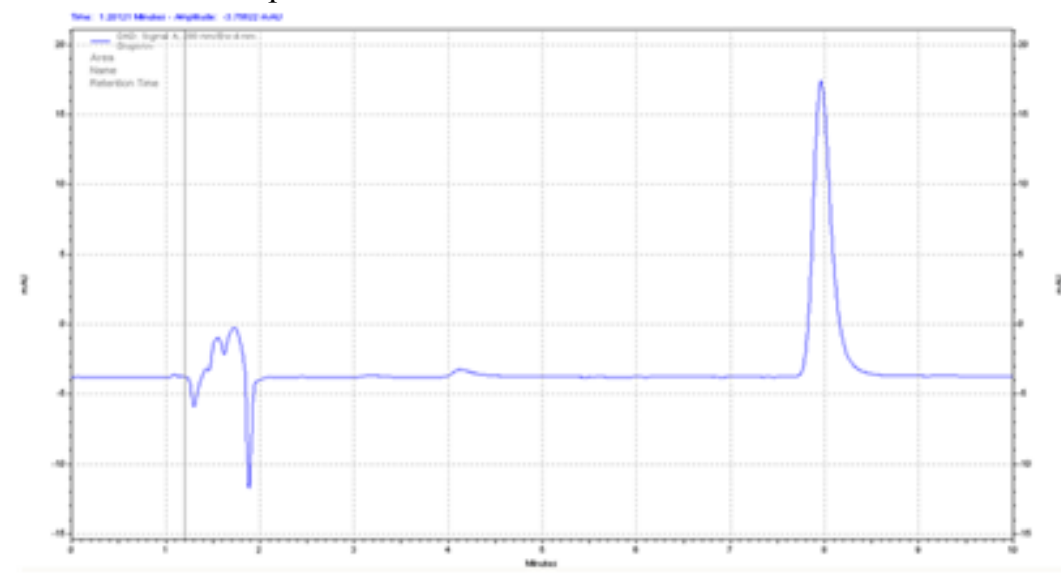

HPLC Spectra of Disprin Sample 


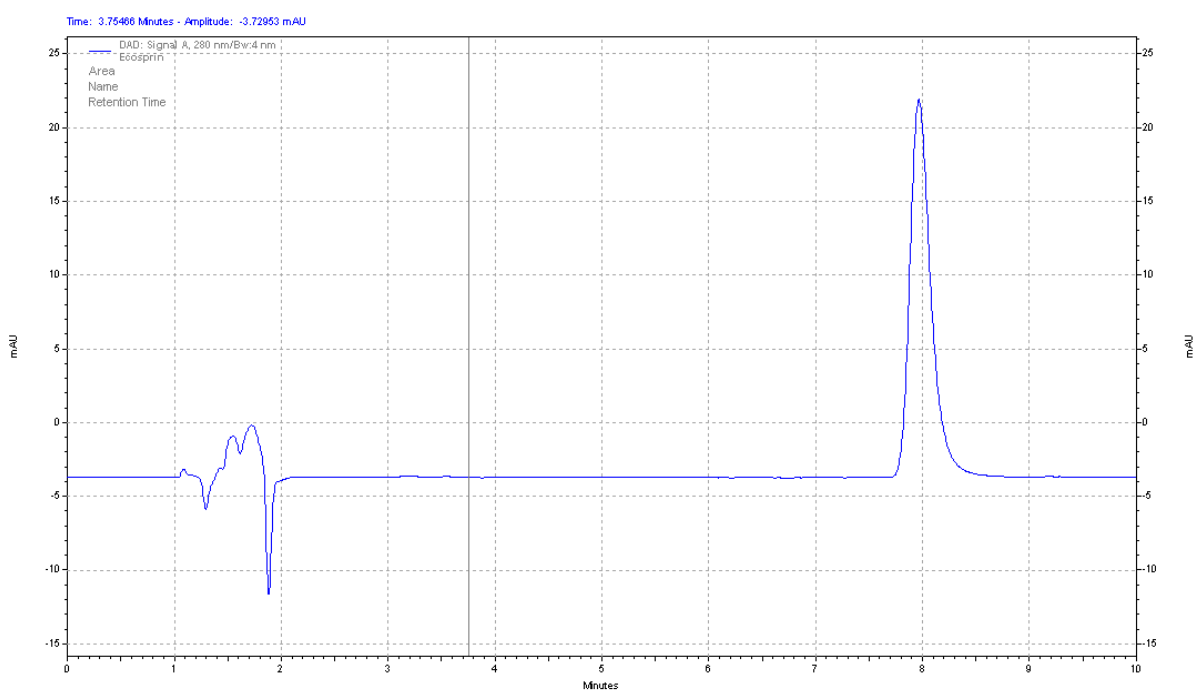

HPLC spectra of Ecosprine sample

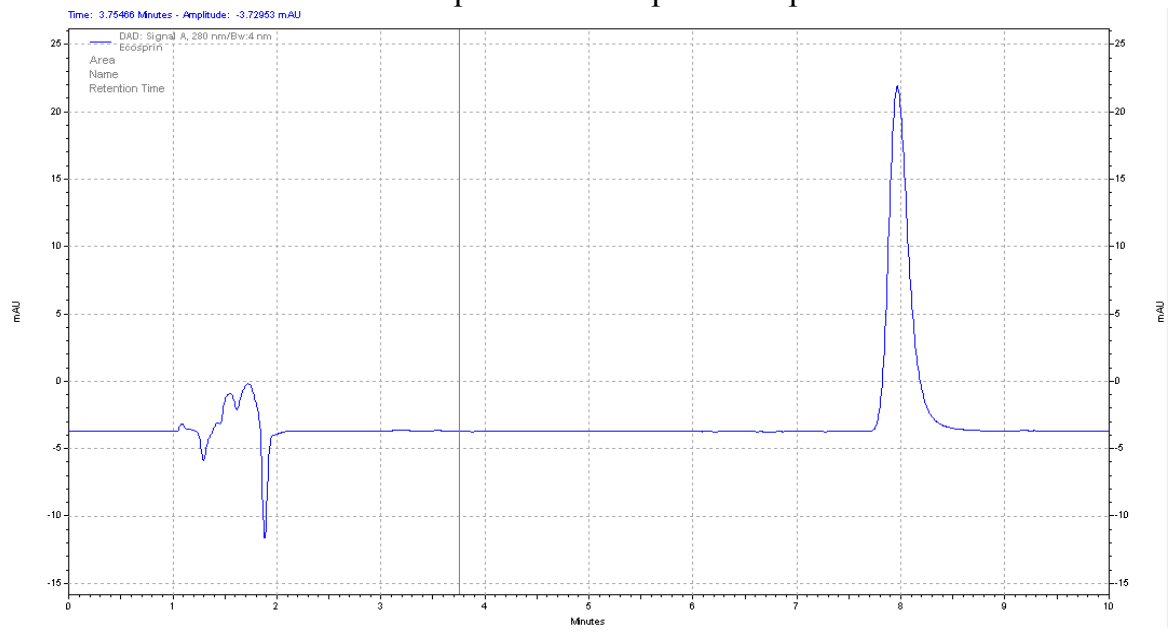

HPLC spectra of Loprine sample

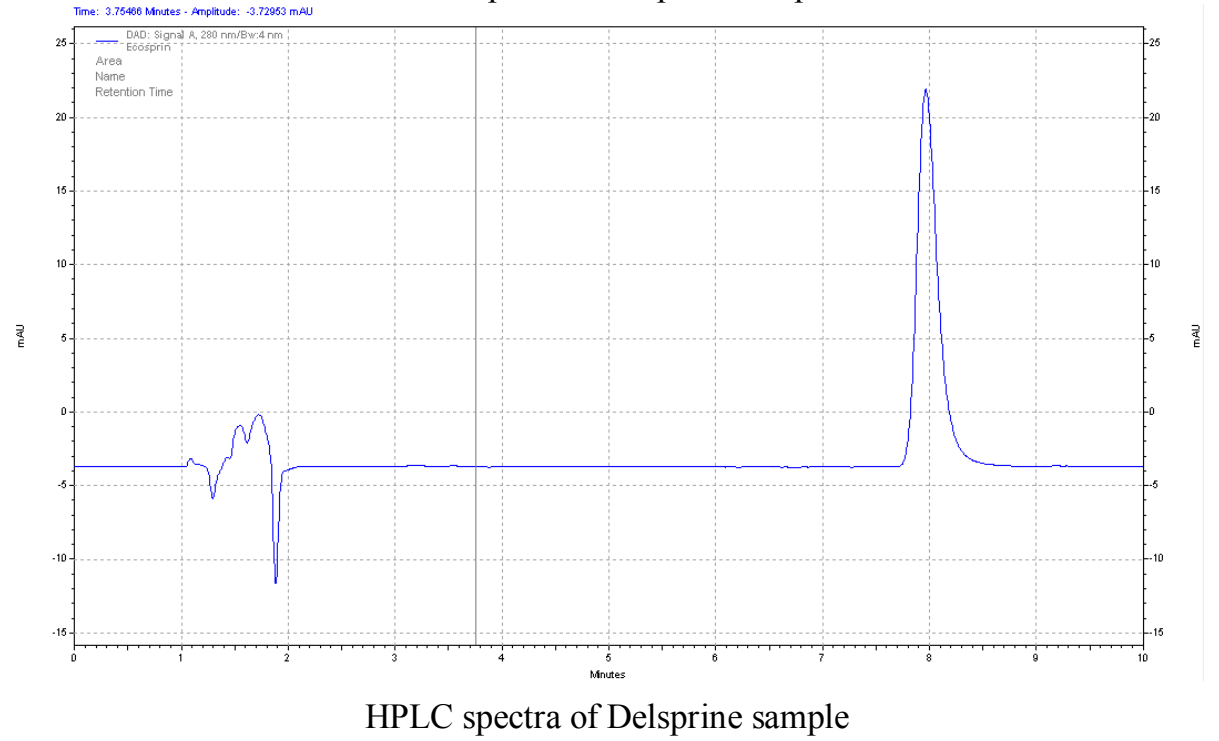




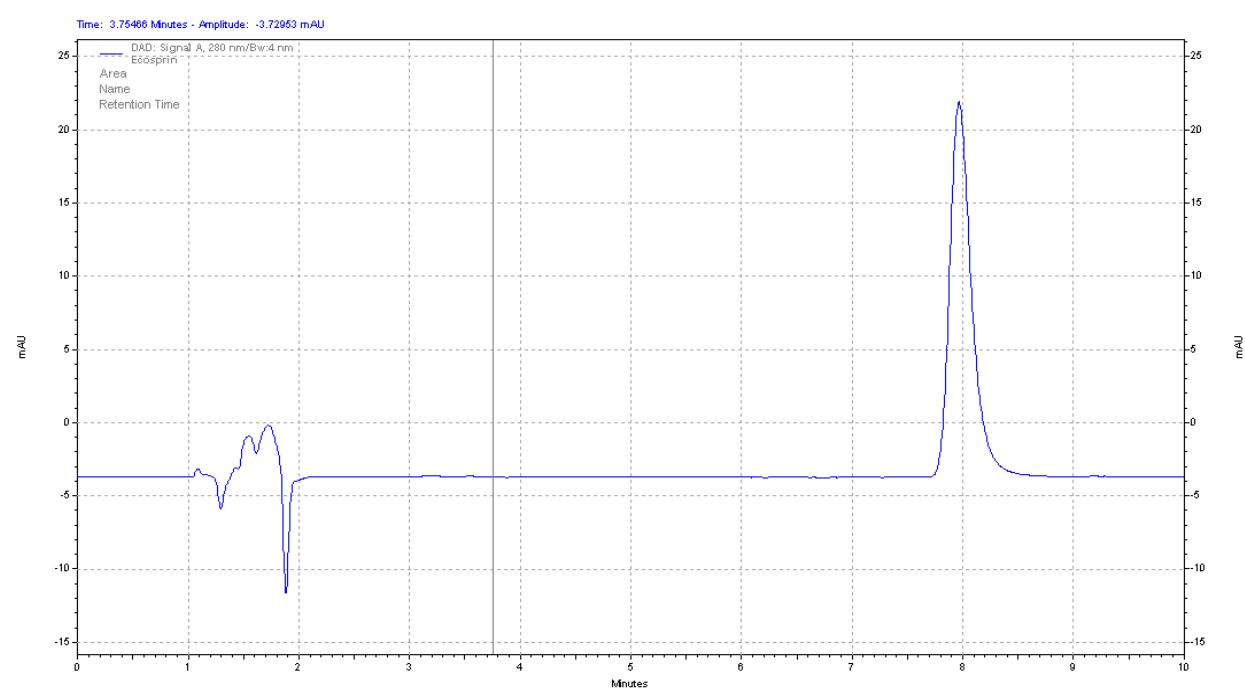

HPLC spectra of ADR Sample

\section{Conclusion}

Despite the number of methods described by different researchers for analysis of acetyl salicylic acid, the proposed UV-VISIBLE Spectrophotpmetric method and HPLC method for determination of acetyl salicylic acid in pharmaceutical samples is simple and rapid than other sophisticated instruments. All the samples analyzed were within the range as prescribed on tablet. These methods are very appropriate for routine analysis of active drugs in the laboratories. The procedures are easy to execute and require less sample handling than methods described in the literature. The following table gives the summary of result.

Table No.5

\begin{tabular}{|c|l|c|}
\hline Sample & $\begin{array}{l}\text { \% Recovery Of Asprine By Uv-Visible Spectrophotometry } \\
\text { Method }\end{array}$ & \% Recovery Of Asprine By HPLC Method \\
\hline Disprine & 97.70 & 97.80 \\
\hline Ecosprine & 98.73 & 98.86 \\
\hline Loprine & 96.85 & 96.40 \\
\hline Delsprine & 99.75 & 99.07 \\
\hline ADR & 98.22 & 98.02 \\
\hline
\end{tabular}

\section{References}

[1]. Aspirine overdose 123Helpme.com 23June 2014

[2]. 2) Zenon KoKot, Kinga Burda: Journal of pharmaceutical and Biomedical analysis: vol.18, Issue 4-6, Dec- 1998. Page 871-875.

[3]. Ghulam Murtaza, Izhar Hussain, Shujaat Ali Khan, Arham Shabbir, Arshad Mahmood, Muhammad Hassham Hassan Bin Asad, Kalsoom Farzanal andNadia Shamshad Malik, Scientific Research and Essays Vol.6(2), pp. 417-421, January 2011.

[4]. Angel A.J.Torrero, Juan M. Luco, Leonides Sereno, Julio Rabr, Talanta, Science Direct Volume 62, Issue 2, 6 February 2004, Pages $247-25$

[5]. J.T.Franeta, D.Agbaba, S.Eric, S.Pavkov, M.Aleksic, S.Vladmirov, Science Direct volume 57 Issue 9, September 2002, Pages 709713

[6]. Augustin Catallin, Moț, Florin Soponar, Andrei Medvedovici \& Costel Sârbu, , 24 Feb 2010, Taylor and Franc

[7]. Saadet Dermis and Ekram Dydogen, Department of Analytical Chemistry, Faculty of Pharmacy, University of Ankara, June 20,2009, Commun.Fac.science University, ANK Series 